\title{
MANAGEMENT CONSIDERATIONS FOR THE HEARD ISLAND LAVA TUBE CAVES
}

\author{
by Kevin Kiernan and Anne McConnell \\ (with one text-figure and two plates)
}

\begin{abstract}
Kiernan, K. \& MCCONnell, A., 2000 (30:vi): Management considerations for the Heard Island lava tube caves. In Banks, M.R. \& Brown, M.J. (Eds): HEARD ISLAND PAPERS. Pap. Proc. R Soc. Tasm. 133(2): 13-22. https://doi.org/10.26749/rstpp.133.2.13 ISSN 0080-4703. Department of Geography and Environmental Science, University ofNewcasde, Callaghan, NSW, Australia; postal address 15 Summerleas Road, Fern Tree, Tasmania, Australia 7054.
\end{abstract}

Heard Island contains a system of lava tube caves in a largely pristine condition which are the best developed bedrock caves known in Antarctic or Subantarctic latitudes. They require special management, because of significant and sometimes fragile attributes associared with cavegeomorphology, geology, hydrology, atmospheres, soils, microbiology, flora, fauna, vertebrate palaeontology, archaeology and safety considerations. Use for recreation, tourism or science may pose serious impacts on these cave environments. Restricted access under the Heard Island Wilderness Reserve Management Plan would be an appropriate management response.

Key Words: lava tubes, geoconservation, cave management, Heard Island, Subantarctic.

\section{INTRODUCTION}

A small complex of lava tube caves occurs at Azorella Peninsula in the Heard Island Wilderness Reserve and World Heritage Area, located in the southern Indian Ocean at $53^{\circ} 06^{\prime} \mathrm{S}, 73^{\circ} 24^{\prime} \mathrm{E}$ (fig. 1). Caves can be significant natural heritage assets because of their intrinsic value, their importance to ongoing natural processes, including ecological processes, or their instrumental values, such as their utility for scientific research, recreation or commercial tourism (ACIUCN 1996, Watson et al. 1997). This paper reviews the importance of the Heard Island caves, their vulnerability, safety issues associated with their presence, and their management under the Heard Island Wilderness Reserve management plan.

While these caves have long been known, they appear to have been treated as minor curiosities and paid little attention. Only recently has there been significant documentation of them (Kiernan et al. 1998). Because of their isolated setting and the very limited human intrusion, an opportunity, rare for such caves, exists to retain them in an essentially pristine condition. However, the caves are very close to Atlas Cove, where most people land on Heard Island. Increasing shipborne tourism poses risks to Subantarctic island environments (Cessford \& Dingwall 1998), but government personnel can cause environmental harm in areas to which tourists are denied access, if appropriate management policies are not developed, understood and adhered to by all (Riffenburgh 1998).

Lava tube caves form when a flow of molten lava cools sufficiently to congeal and form a roof which remains after lava drains from the flow interior. Several modes of tubeflow initiation have been proposed (Ollier \& Brown 1965, Peterson \& Swanson 1974, Hon et al. 1994). Once established, tubes may enlarge by "thermal erosion" and localised mechanical incision by flowing lava (Coombs and Rowland 1994, Greeley et al. 1998, Kauahikaua et al. 1998) and through ceiling breakdown, especially where fallen blocks are swept away by still flowing lava (Kempe 1997, Kempe \& Oberwinder 1997).

Lava tubes are known from Subarctic environments in Alaska, Iceland and Kamchatka (Jonsson 1991, Stefanson
1991, Slezin \& Tsyurpa 1994), but the lava tubes on Heard Island represent the only record from Antarctic and Subantarctic latitudes (S. Harris, Arizona State University, compiler of the National Aeronautics and Space Administration's world data base on lava tubes, pers. comm. 25 June 1997). Elsewhere in the Indian Ocean, lava tubes are known from Mauritius and Reunion (Audra 1996, Middleton \& Halliday 1997). The most extensive Australian lava tubes occur in the Undara lava flow in North Queensland (Atkinson \& Atkinson 1995), and in the Newer Volcanics Province of western Victoria (Ollier \& Brown 1965, Webb et al. 1982).

Lava tube caves may be important nature conservation targets, either in their own right as landforms or because of other values they contain. For example, lava tubes allow

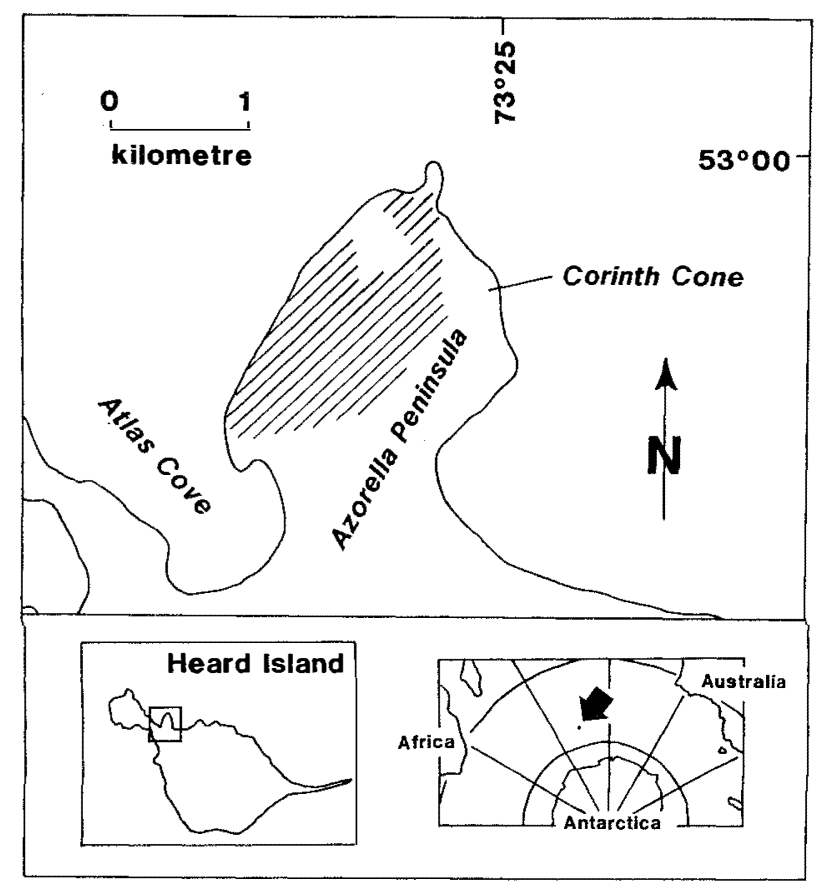

FIG. 1 - Location of Heard Island and Azorella Peninsula. Cavernous tube-fed lava flows occur in the shaded area. 
insight into the mechanisms whereby long lava flows form on minimal slopes as basaltic plains and shields, and also contribute to understanding some aspects of interplanetary geology. Subsurface tubes permit discharge of large volumes of lava very efficiently over long distances with much less heat loss than at the lava surface; this allows the development of extensive, low gradient lava flows. (Cruikshank \& Wood 1972, Hatheway \& Herring 1970, Greeley 1991, Baloga et al. 1995). Caves provide buffered, dark habitats where life forms sometimes exhibit such adaptations as degeneration or total absence of eyes, lack of body pigment and long sensory appendages (Muchmore 1982, Briggs 1992, Crawford 1992, Howarth 1994). Over 50 cave-adapted invertebrate species have been recorded in Hawaiian lava tube caves (Howarth 1977).

Lava caves are complex, interactive natural systems and their management commonly needs to be integrated with that of the adjacent surface environment (Seesholtz 1997). Many cave resources are susceptible to damage or destruction, and non-destructive entry to some caves is not possible. Caves do not have a carrying capacity in the generally accepted sense (Aley 1975), because any recovery generally occurs over geological rather than human time-scales. Damage is cumulative, and often the first intrusions cause the most damage. A conservative approach to cave management can shield potential values even before their existence is recognised (Nieland et al. 1977). The precautionary principle caters for potential threats of serious or irreversible environmental damage, and requires that lack of scientific certainty should not be a reason to postpone measures to prevent environmental degradation. The precautionary principle is acknowledged in the Australian Natural Heritage Charter (ACIUCN 1996), which provides standards and principles for the conservation of places of natural heritage significance.

The inscription of the Australian Territory of Heard Island and McDonald Island (HIMI) on the World Heritage List on 3 December 1997 was based on its exceptional natural beauty, geoscientific values, and significant ongoing ecological processes. The caves of Heard Island are an important part of this World Heritage Area, but are not addressed by the present management plan for HIMI (Australian Antarctic Division 1995).

\section{THE LAVA CAVES OF AZORELLA PENINSULA}

Successful protective management of cave environments generally requires an understanding of the values known or potentially present, their likely sensitivity to disturbance and a decision as to the level of human impact acceptable. Acquiring an understanding of the values and the natural processes that sustain them that is sufficiently comprehensive to facilitate soundly based management decisions is commonly a lengthy procedure, even for readily accessible and well-researched caves (e.g. Manidis Roberts 1994). It is very much more difficult for remote, poorly known caves, where data gathering is difficult and expensive. Where management decisions nevertheless need to be made, some guidance can be gained by analogy with the most comparable cave environments elsewhere. In the paragraphs that follow, confirmed values of the Azorella Peninsula lava tubes are reviewed, and other values that may be present are identified by analogy with lava caves elsewhere. This approach is consistent with Article 5 of the Australian Natural Heritage Charter, which provides that the conservation of a place should take into consideration all aspects of its natural significance without unwarranted emphasis on any one aspect at the expense of others.

\section{Geomorphology}

The Azorella Peninsula lava tubes have been described elsewhere (Kiernan et al. 1998) and are merely summarised here. In common with many lava tubes elsewhere, these caves are associated with surface landforms produced by lava inflation, a process that results from the injection of mobile lava beneath congealed crust, physically raising the lava surface by hydrostatic pressure (Walker 1991, Mattox et al. 1993, Hon et al. 1994, Cashman et al. 1998). The longest accessible tube segment documented ro date is $-200 \mathrm{~m}$ long, up to $8 \mathrm{~m}$ in diameter and lies at only a few metres depth. Strand lines and benches on the tube walls record successive levels of the internal lava flows, and variations in tubc floor morphology record stages in their cooling (pl. 1), the breakout of tube-fed liquid lava beyond a stagnated flow and evidence of lavafall erosion. Small lava stalactites and stalagmites also occur, some extended by secondary minerals precipitated from seepage water. Some roof-fall blocks occur beneath intact ceiling linings, and lava stalagmites have formed on some fallen blocks, both implying breakdown during initial tube formation. Two open vertical volcanic conduits (OVCs) (Skinner 1992) occur near Corinth Head. OVCs are rare, as they are often rapidly filled by collapse and debris accumulation (Hatheway \& Herring 1970, Jonsson 1991, Favre 1992, Halliday 1997). The only other OVC in Australia is at Mt Eccles in Victoria (Webb et al. 1992).

Study of these landforms on Heard Island remains incomplete. The morphology of lava tubes reflects their diverse geological influences, topographic settings, modes of genesis, stages of development and other factors. Caves and sinkholes can act as sediment sinks and retain wash from the surrounding landscape that may be important for palaeoclimatic reconstruction. Secondary cave minerals can reflect climatic or hydrological conditions or biological colonisation of caves and, hence, may allow insights into

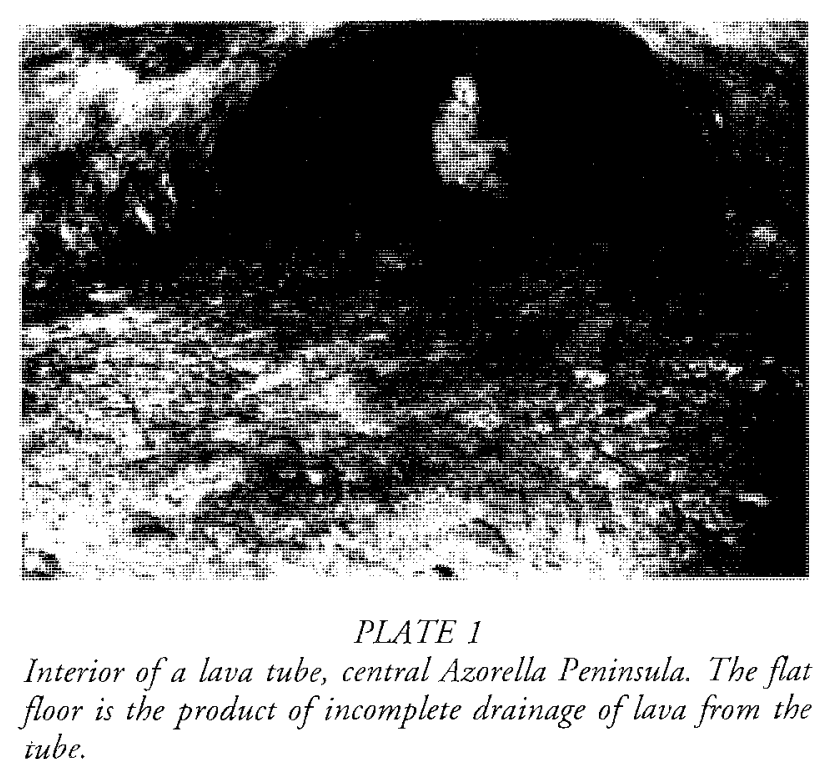
iube. 
palaeoenvironments and biological evolution. Caves in basalt tend to contain a greater range of minerals than do karst caves, due to contributions from the host rock and interactions with volcanic fumes, guano from caveinhabiting biota and soils (Hill \& Forti 1986, Pilkington \& Segnit 1979, Webb 1986, Grimes \& Watson 1995, Halliday 1995). Thick guano accumulations in one Heard Island lava tube (Brown 1957) have potential for mineralogical, dating and palaeoenvironmental studies.

\section{Bedrock Geology}

The volcanic geology of Azorella Peninsula is little studied. Lava tubes and related features can provide exposures of subsurface geological structures and rocks not otherwise accessible. Some lava layers exposed in these caves lack cooling crusts and have strings and lava dribbles stretching across the voids. This suggests the layers are not all individual flow units. Lava tubes can provide insights into volcanic plumbing and decp stratigraphy, eruptive histories, rates of effusion and flow duration, while vegetation casts or palaeosols may be encountered in cave walls (Wood 1992).

\section{Palaeontology}

Bone deposits in caves may be the remains of cave dwellers, their prey devoured in caves or victims of natural pit trap effects. Any bone deposits in caves or sinkholes of Azorella Peninsula are an unknown quantity, but these are likely sites for bones, given their occupation by penguins (Brown 1957). Bones may reveal extinct species, past patterns of animal distribution and broader environmental evolution (Wakefield 1964, Olsen \& Wetmore 1976).

\section{Hydrology}

Layered lava, vertical joint systems and lava tubes are more prone to infiltration than most geological terrains. No detailed understanding exists regarding the hydrology of Azorella Peninsula, water quality or use of the groundwater by underground biological communities. There is abundant seepage into some of these caves, but concentrated flows are relatively rare, despite the shallow depths and high rainfall. Moisture on some cave walls is condensation rather than seepage, while some cave passages are remarkably dry. The caves offer potential for study of the hydrology of a lava flow in an unusual climatic setting.

\section{Cave Atmospheres and Cave Climatology}

Cave atmospheres are of scientific interest in their own right and are also an important influence upon some speleothems and fauna. No work has been undertaken on any aspect of the atmospheres and microclimates of the Heard Island caves. Cave temperatures are generally influenced by cave wall temperature, external conditions, passage configuration, entrance location, conduction through walls, and through the exchange of latent heat by condensation or evaporation. Some lava tubes remain warm due to geothermal heat release, while others function as cold air traps (Jonsson 1991, Halliday 1977, 1995). The Heard Island lava tubes are shallow and the overlying soils thin; hence, some surfacedriven temperature changes are likely (Benedict 1977). An ice plug was recorded in one entrance in March 1997, when ice masses were at their seasonal minima; hence this plug may be permanent. Underground ice occurs in lava tubes in the Northern Hemisphere, but permanent underground ice is unrecorded from any orher lava caves in the Southern Hemisphere or from caves of any other kind at southern latitudes equivalent to Heard Island.

Free air movement occurs in the more spacious and open lava tubes but is inhibited by blockages of rockfall debris, fine sediment and ice. Air movements may be caused by chimney and reverse chimney effects; the adjustment of the cave atmosphere to barometric fluctuations in the external environment; the gravitational drainage of air into single entrance caves; the resonance of air in large chambers (cave breathing); or other factors (Wrigley \& Brown 1976). Interstices between lava layers may play a significant role in ventilation of these lava caves.

Atmospheric $\mathrm{CO}_{2}$ levels may vary, due to the in-wash and decomposition of organic material and the degassing of infiltration waters. Light penetration, air quality and humidity are significant to cave biota. Four habitats are recognised in caves (entrance, twilight, transition and deep cave zones) with the most highly cave-adapted species occurring in the deeper and darker parts of caves. A fifth stagnant air zone enriched in carbon dioxide can be found in dead-end passages beyond configurations that trap water vapour or carbon dioxide, or where air intake has been precluded (Howarth \& Stone 1990).

\section{Pedology}

There has been limited pedogenesis upon these young lava flows. The regolith over the caves includes reworked volcanic ash, while organic soil is related to the thick Azorella mounds and to nutrient inputs and burrowing by birds (Australian Antarctic Division 1995). This singular tube-fed lava flow landscape in Subantarctic latitudes may yield soil types unusual for lava tube environments. Soils have important implications for botanical colonisation and for the evolution of soil and cave fauna. Voids in cavernous lava sometimes initially allow free drainage and a steep hydraulic gradient directly downwards, but root penetration and the entry of nutrients may become inhibited as soil particles clog drainage routes (Howarth 1994). Some soils on Azorella Peninsula are relatively erodible, with potential for loss underground.

\section{Microbiology}

Reflective white dots on the ceilings of some of these caves appear similar to features elsewhere shown to be very large colonies of actinomycete bacteria. Bacteria also inhabit other cave niches. Elsewhere, bacteria and cyanobacteria that have the capacity to derive energy from reduction or oxidation of iron or sulphur compounds support food chains for cave invertebrates. Microbes have been implicated in the formation of some iron and manganese oxides, sulphur compounds and other cave minerals. The retention of prisrine sites is important for work in these fields and on microbial diversity generally. Caves offer important opportunities for new understanding of the evolutionary relationships of bacteria and fungi. Models of possible life 
on Mars are being developed through study of microbial communities in subsurface environments on Earth, while the discovery of chemical substances in cave microbes that are effective in fighting forms of cancer adds another dimension (Northup et al. 1997).

\section{Botany}

No botanical studies of the cave entrances has been undertaken (Bergstrom \& Seppelt 1988, Scott 1990). Distinctive plant communities may develop in some tubefed lava landscapes (Johnson et al. 1968), partly because water may rapidly be lost underground into subsurface void systems producing a degree of relative aridity. Young lava flows lack mature soil profiles that facilitate water retention, so the vegetation is often relatively xeric, regardless of climate. Special environments often exist in sinkholes where cold air is ponded, there is movement of air into and out of cave entrances, seepage water is concentrated or there is shelter from strong winds (Crawford 1992). Distinct local sinkhole communities may develop (Nieland et al. 1977 , Joyce \& Webb 1992); thus, 20 fern and 62 moss species, lichens and liverworts coexist at the Byaduk lava caves in western Victoria (Beaglehole \& Learmonth 1957).

\section{Zoology}

The use of these caves by birds has left eggs within some, while Brown (1957) records a colony of rockhopper penguins (Eudyptes chrysocome) in another, and we know of no other lava rube area with such an occurrence. No systematic investigation of the invertebrate fauna of the Heard Island lava tubes exists but, by analogy with lava tubes elsewhere and a relatively diverse invertebrate fauna on the surface (Gressit 1970, Horne 1984, Dartnall 1995, Australian Antarctic Division 1995), there is the potential for biospeleological investigations.

Potential food enters these caves from the surface via gravity fall down entrances, entrainment by water or air flows, and carriage underground by animals. Potential energy sources underground also include penetrant plant roots, eggs, guano and carcasses. Shallow lava tubes are readily reached by seepage water rich in dissolved and fine particulate organic matter, which supports heterotrophic bacteria that may form lava tube slime. While organic inputs occur relatively evenly over time and space rather than in the stream-borne pulses found in karst caves (Howarth 1994), the community structure and bioenergetics of lava tubes and karst caves are broadly similar, apart from the nature of the energy source and the taxonomy of the biota (Crawford 1992). Surface climate and floristic diversity generally determine the rate of succession in lava caves, with the most diverse cave communities occurring in young, well-vegetated lava flows (Howarth 1994).

These lava tubes are very young, but cave-obligate fauna has been found in other young lava tubes, where species have been able to evolve in earlier caves and disperse through voids such as those between lava layers. There can be an ongoing cycle of void formation and occupation, blocking of voids by collapse or clogging with the residues of rock decomposition, and the migration of faunas into newer void systems (Crawford 1992). New lava flows reset biological succession both above and below ground; successive lava flows provide new subsurface void systems, offering near-surface habitat that may be colonised by fauna from older, deeper lava flows. This upward extension of potential subterranean biospace and succession in lava caves contrasts with the situation in karst caves, where potential biospace is formed at progressively greater depth as streams cut deeper, but in both cases the new caves may be colonised by older faunas (Howarth 1994). The better developed shallow intermediate void spaces that occur in lavas may initially be penetrated by plant roots that are important energy sources for cave invertebrates. Ash may have clogged some infiltration routes here, while the herbaceous vegetation gives less potential for deep root penetration than occurs in the tropical rainforest lava terrains, where highly developed lava cave faunas have been recorded. If the earliest eruptions on Azorella Peninsula are comparable in age to those on the adjacent Laurens Peninsula, then subjacent void space is probably Holocene, perhaps limiting the potential for a well-developed troglobitic fauna. Limestone underlying the lavas of Heard Island exhibits some karst landforms (Australian Antarctic Division 1995) and provides another possible source for cave adapted fauna to colonise the lava tubes (Crawford 1992).

\section{Archaeology}

There is no evidence of prehistoric human occupation of Heard Island, but the historical archacology includes sealing and scientific sites. Lazer \& McGowan (1990) recorded occupied caves on Heard Island but did not investigate the lava tubes. Caves have the potential to contain structures such as cleared areas, walling, entrance modifications or sediments that incorporate evidence of earlier human use and adaptation.

\section{CAVE MANAGEMENT CONCERNS}

The growing world literature on cave management is related primarily to karst caves but it contains some elements adaptable to lava tube management (Davey 1984, Kiernan 1988, Watson et al. 1997). Lava caves are also sensitive to human impacts. For example, lava stalactites and stalagmites formed in a volcanic eruption cannot regenerate, unlike the continued growth of stalactites in a karst cave. But important differences between lava caves and karst caves relate to fundamental differences in the morphology, genesis and functioning of these two types of cave. Lava tubes form shallow and predominantly horizontal caves, successive lava flows producing new primary cavities close to the surface, whereas karst caves evolve as integral parts of hydrological systems, subterranean waters dissolving out cave passages at increasing depth in a rock mass that may otherwise lack many open fractures. Lava layering facilitates the circulation of water and air, energy, biota and nutrients, and the influence of outside air circulation on shallow and short lava tubes contrasts with more buffered deep karst caves. Lava layers, sealed behind melted tube wall and roof linings, offer additional biospace where troglobitic invertebrates occupy interconnected cavities that are too small for human entry (Crawford 1992, Chapman 1993). 


\section{Potential for Damage to Cave Resources}

If the primary goal of managing a cave is the protection of its intri nsic values or natural process values, then management interve ntion becomes necessary only in the event of unnatural perturbations. If the only value of a cave is perceived ro be its instrumental value for science, recreation or commercial tourism, its intrinsic or natural process values may be compromised by such use. The environmental harm can either beaccepted, or management may intervene to reduce it. The nature of the activity conditions the kind and degree of damage.

Large bedrock and geomorphological features in caves are relatively robust, but smaller features are more vulnerable. Shelly pahoehoe lava blisters and florets of aa lava that floor some passages at Heard Island are very susceptible to breakage by visitors, lava stalactites can be broken, soft clastic speleothems and sediments can be trampled and eroded and features buried by sediment that is disturbed (Nieland et al. 1977, Halliday 1995). Overzealous geological collection (amateur, scientific or commercial) has taken a toll in some other Australian lava caves and could do so here (Joyce \& Webb 1992). Any applications for geoscientific collecting from these caves need careful assessment, recognising that multiple access may compound damage. The potential for sharing samples and lodging of specimens in a sample bank should be considered.

Bone deposits in earthy matrix are commonly dismissed as "just dirt" by casual visitors. Protection is necessary to minimise crushing, erosion and spreading of sediment deeper into the cave environment by foot traffic, and to protect the entrance vegetation. Bones are also easily damaged by the instigation of drainage changes that lead to erosion, collection, artificially induced microclimatic changes that alter weathering processes, or changes in the moisture status of sediment matrix or the chemistry of water that reaches bone deposits. Activities of fossil collectors, some commercially motivated, are difficult to manage in remote localities.

Environmentally detrimental changes to the flow regime and quality of the groundwater may be caused by human activities above or below ground. In lava tubes, the void systems form natural pipes, permitting rapid transmission without the natural filtering and purification found in geological terrains where fabric selective porosity predominates. Water in lava tubes is important to maintaining natural heritage values, including biological habitats and the continued growth of secondary speleothems.

Cave atmospheres and microclimates may be altered by blocking or digging open entrances or passage constrictions, changing fauna habitats and preventing research into natural cave microclimates. A $1{ }^{\circ} \mathrm{C}$ increase in cave air temperature raises its water vapour capacity by $8 \%$ and can result in a ten-fold increase in evaporation, with adverse implications for some secondary speleothems and invertebrate cave faunas (Williams 1975). Even human body warmth can temporarily but appreciably change cave temperatures. Air quality changes are compounded by carbide lamps, candles and smoking cigarettes underground.

Even scientific investigation of the cave ecosystems risks the environment; for example, the colony of penguins in an Azorella Peninsula lava tube is considerably disturbed when humans intrude into their dark and confined underground home (Brown 1957). While an invertebrate biology in the lava tubes may add to the faunal values, visitors have potential to impact upon invertebrate fauna species survival, because the total population of cave species can be very small. The loss of even a few individuals may trigger extinctions or accelerate the pace of genetic drift (Howarth 1981). Cave fauna may react to changes in food supply, and some materials left by visitors are readily colonised (Spate \& Hamilton-Smith 1991). Floor-dwelling and aquatic invertebrates and their environment may be trampled and impacted, with species restricted to particular substrate types being most vulnerable (Eberhard \& Hamilton-Smith 1996). A variety of management responses may help, such as delineating substrate protection zones and confining foot traffic to defined paths. Some cave fauna is disturbed by torchlights or unusual noise. Howarth (1992) reports of Hawaiian lava tubes:

Our field data show that, other factors being equal, species diversity and population levels of cave organisms is inversely proportional to the level of visitation and human disturbance.

Much invertebrate cave fauna is almost "aquatic" in character. Resolution VI.5 from the 1996 Ramsar Convention on the Conservation of Wetlands and Waterfowl determined that subterranean karst and cave hydrological systems should be added to the Ramsar wetland classification system. Because many cave faunas are highly susceptible to changes in atmospheric humidity and some are dependent upon high $\mathrm{CO}_{2}$ atmospheres, excavations for access into further caves or cave passages is unwise.

Undisturbed microbial communities could be changed by human importation of foreign microbes and organic matter, in such forms as skin flakes, food and lint, that displace organisms adapted to highly oligotrophic conditions (Northup et al. 1997). The relatively pristine condition of the Heard Island lava caves is an important consideration.

Visitors to these caves disturb vegetation in entrances, sinkholes and along access routes, accelerating soil erosion. The sinkholes host visually delightful sunken gardens, which it would be a shame to see disfigured (pl. 2). The Azorella selago mounds on Azorella Peninsula are particularly susceptible to trampling, and imprints can last for a long time. Experienced individuals can reduce vegetation damage using suitable foot placements and footwear, but not all potential visitors have had this experience. Small bedrock inflation landforms, themselves vulnerable to breakage,

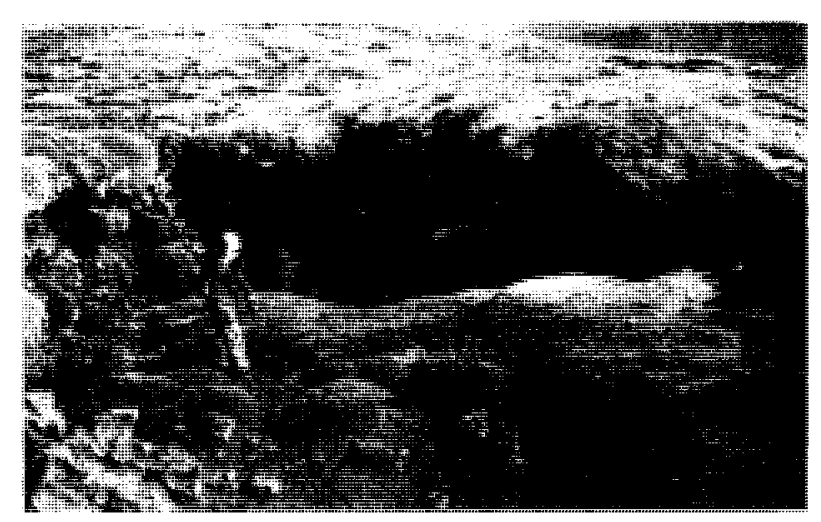

PLATE 2

Vegetation, predominantly Azorella selago, in a sinkhole that contains the entrance to a lava tube cave. 
sometimes provide alternatives to walking on the vegetation; elsewhere, bare soil surfaces may be riven by bird burrows that collapse underfoot.

Damage may be caused to archaeological resources by foot traffic, souveniring, or various other activities - in some cases publication of information concerning archacological resources in lava caves has led to looting (Howarth 1992). Visitors to the Azorella Peninsula caves need to be aware of the sorts of cultural heritage features they might inadvertently disturb.

\section{Potential for Damage to Human Visitors}

Cave environments are often unforgiving of the ill-prepared, in experienced or incautious. The deep OVCs have sloping entrance funnels of loose scoria that are potential "ant traps" for people who do not exercise caution. Underground, steep slopes, slippery surfaces, shadowy deep holes or shafts all offer the potential for accidents, while some cave ceilings are locally unstable. The risk of hypothermia in the event of injury and delayed rescue is very high. The Australian Speleological Federation Inc. (1990) cave safety guidelines, although not geared directly to the Heard Island environment, provided valuable general advice.

Cave rescue is a specialised enterprise, and generally very time consuming. Where accidents occur remote from trained rescue personnel, inexperienced personnel may be forced to attempt rescue, posing a serious risk of additional people becoming trapped or injured. Rescue would most likely be a protracted affair, even without physical entrapment that might require specialised equipment to lift rocks or the need to retrieve a victim from beyond a narrow passage constriction. The environmental costs could be great.

While the potential risks to human health posed by such known cave hazards as contaminated water, diseases or radon gas are probably very low, their consideration forms part of the duty of care of any cave management authority. For example, the potentially fatal disease histoplasmosis is a known hazard for cavers who visit bat roosting sites but is especially suited to avian habitats (Ibister et al. 1976, Hunt et al. 1984, Harden \& Hunt 1985). The fungus Histoplasmosis capsulatum, which causes the disease colonises soil contaminated by faeces, and infectious spores may be inhaled when this is disturbed. Histoplasmosis is generally considered a hazard of the tropical and temperate environments, but the potential for it to exist in Subantarctic caves is untested, since no other caves inhabited by large bird populations have been recorded from Subantarctic latitudes. The radioactive gas radon, produced by the decay of uranium, and its microparticulate daughter products occur in some karst caves and may contribute to lung cancer. Casual visitors to caves are unlikely to accumulate a harmful dose (Solomon et al. 1996) but, given higher uranium concentrations in volcanic rocks than in limestone, the potential may exist for radon levels to be higher in less well ventilated passages.

\section{Implementing Management of the Heard Island Lava Tubes}

Protection of the HIMI environment is provided for by the Territory of Heard and McDonald Islands Environment Protection and Management Ordinance 1987, the Environmental Protection (Impact of Proposals) Act 1974, the Australian Heritage Commission Act 1975 and the World Heritage Properties Conservation Act 1983. Other legislation relevant to management decisions that affect lava cave fauna includes the National Parks and Wildlife Conservation Act 1975 and, potentially, the Endangered Species Protection Act 1992. Heard Island is administered by the Australian Antarctic Division in accordance with a management plan that sets out the vision (Australian Antarctic Division 1995):

Acknowledging the outstanding natural qualities of the Territory of Heard and McDonald Islands, and its great importance to the ecosystems of the Southern Ocean, management of the Territory will allow natural processes to proceed with minimal human intervention and will assign highest priority to conserving its environment, its value to research and its unique cultural heritage.

The present edition of the plan designates several seldom or never visited Restricted Access Areas that have been established as important scientific reference points providing as near to natural conditions as possible, to remain free from human interference except for essential management or compelling research purposes. The criteria upon which research within a Restricted Access Area might be considered "compelling" are not spelt out in the management plan. The Plan also provides for the designation of Specially Protected Areas to enable closure of part of the Territory to otherwise permitted uses through the permit system, in order to protect sensitive phenomena or for human safety. Under the present plan the area around the caves is zoned as a Wilderness and Heritage Area with cited values of little recent human impact. However, Azorella Peninsula adjoins a Main $U_{s e}$ Area, which puts potential visitor pressure on the lava caves. While the very remote setting of Heard Island inhibits human activity, it also militates against effective site management. Potential use scenarios involve casual recreational visits by expeditioners, organised cave tourism and scientific investigations.

The impact of recreational caving parties depends upon the number of participants, their attitudes, experience and skill. The attractiveness of the caves as venues for recreation may be diminished if important attributes are degraded. Accrued recreational impacts recognised here in March 1997 were localised but included trampling of entrance slopes, litter and damage to vegetation along access routes. The Australian Speleological Federation (1995) has developed a set of minimal impact guidelines for caving which acknowledge that even experienced cavers can have adverse environmental effects, that every trip has an impact and that its real worth should be carefully assessed. Any permitted entry to the Azorella Peninsula caves should be conditional upon compliance with these guidelines at a minimum, and with draft guidelines for the protection of microbial communities in caves presented by Northup et al. (1997).

Sensitive caves generally fare best when their existence simply remains unknown to potential users. The American National Speleological Society (NSS) formally discourages 
reporting recreational use of Hawaiian lava caves (Howarth 1992). Deflecting visitors towards more robust caves can be useful but is a hazardous strategy where other more sensitive caves occur in close proximity, because visitors may stray into the wrong cave. Gating cave entrances may generate significant environmental impacts and is a last resort. Even very basic stringline delineation of pathways is probably undesirable in caves frequented by penguins.

As venues for recreational caving, the relatively small caves of Azorella Peninsula offer little more than the possibility of satisfying casual curiosity or an opportunity to "collect" a cave experience from an exotic locality they do not offer a quality caving experience. Given the other values that may be compromised and the range of alternative recreational opportunities available on Heard Island, it seems inappropriate to exploit the limited recreational caving potential offered by the lava tubes. They deserve better than to be treated simply as underground gymnasiums or playgrounds.

At least one tourist operator has already expressed interest in using these caves as attractions for shipborne tourists, despite the lack of any documentation regarding the extent, potential attractions, environmental sensitivities or safety of the caves. Most caves used for tourism have been "hardened" through the construction of walkways and protective infrastructure, but significant environmental impacts have still been generated (Williams 1975, Kiernan 1988). Where tourism occurs without the establishment of hardening infrastructure, the movement of visitors is unconstrained and floor surfaces are unprotected. In the absence of an effective management presence on site, a tourist guide is an obvious point of contact through whom environmental messages might be conveyed from a management authority to cave visitors, but for this to be successful the guides themselves must be fully conversant with the very special values and sensitivities that caves may hold and committed to their preservation. If the ASF minimum impact caving guidelines were adopted, the maximum caving party size of four might seem economically unattractive and is unlikely to provide an adequate economic return to fund protective infrastructure.

Another hazard posed simply by the proximity of the caves to the main use zone was illustrated during shipboard discussions prior to landing a very large party for the commemoration of the 50th anniversary of ANARE at Atlas Cove. It was proposed by one participant that the caves were close enough to provide useful emergency shelter should weather conditions or mechanical problems prevent the party being returned to the ship at the time planned. Although this proposal was recognised by others to be inappropriate, it highlights the need for appropriate management policies to be developed, understood and adhered to by all.

As interesting and worthwhile as scientific research can be, it has the potential to cause environmental impacts over and above the "base load" a cave environment must endure simply from people being in it at all (Kiernan 1997). Few scientists are also experienced minimal impact cavers and yet they may be involved in initial exploration, when the most serious damage is often caused. Special risks arise even in compiling a comprehensive cave map. More specialised studies involving collection of cave fauna, fossils or minerals, or the installation of scientific apparatus, can also pose risks, and finite resources are depleted where cave sediments are excavated. Often, researchers in one discipline act as if oblivious to other values, perhaps making an unwarranted assumption, consciously or otherwise, that their own field is of greater importance than any other. The real worth and purpose of any proposed research and its environmental impact all require careful scrutiny.

Environmental impact statements for scientific research are required under the management plan but must be properly assessed by qualified specialists and not merely be exercises in fulfilling bureaucratic requirements. At the same time, any cave manager must assess whether decisions by higher powers are likely to be proper professional decisions founded on scientific probabiliries or are more likely to be political or legalistic determinations. This can sometines lead to the unacceptable situation where managers may feel compelled to counter pressures for inappropriate use by allowing research that itself can reasonably be expected to involve serious degradation of a resource, compromising both their own professional standards and the environments in their charge.

\section{CONCLUSIONS}

The rare opportunity exists on Heard Island to retain a small system of lava caves in an essentially pristine condition, but application of the Precautionary Principle is required:

(1) Given the management concerns, the World Heritage status of Heard Island and its designation as a Wilderness Reserve, the adoption of a policy aimed at safeguarding all the natural values of the lava caves to the maximum possible extent would be appropriate. We consider that according primacy to respect for the intrinsic values of these caves should be the starting point for cave management on Heard Island.

(2) If the caves are left undisturbed by humans and the protection of their intrinsic or natural process values is given priority over their instrumental value, then scientific research and management intervention are not likely to be "essential". In our view, active management is only likely to become "essential" if it is decided to exploit the caves in some manner, thus generating a need to fully understand cave resources and their vulnerability, in order to develop means for minimising environmental harm.

(3) Entry to the caves, in order to obtain sufficiently detailed information as to allow informed in-cave management decisions, would inevitably imply some irreparable damage. True adherence to the vision set out in the management plan for the Heard Island Wilderness Reserve may not be consistent with permitting that damage to occur.

(4) Some of the research questions raised earlier might equally well be addressed in other lava cave systems elsewhere that have already been subject to human impact. Similarly, experimental strategies for protection of cave environments would more appropriately be trialed elsewhere, in preference to exposing these caves to unnecessary irreversible damage. (5) Notwithstanding some ambiguity in the Restricted Access Area concept as it presently stands, we believe this is the most appropriate zoning available for the lava tubes under the HIMI management plan. If necessary, they could be designated a Specially Protected Area until the management plan is revised.

(6) Effective protection of these caves is unlikely to be achieved unless there is consultation and agreement regarding its desirability, and understanding of the impact likely to be 
caused by visitation. Because no management presence is maintained on Heard Island, merely prohibiting entry to the cares is not likely to secure their long-term protection. It needs to be supplemented by highlighting other more robust and scenically spectacular sites as more desirable venues for visitors. We applaud initiatives of this kind already being pursued by the Antarctic Division.

(7) While we do not endorse visitation, if it is to be permitted it should be restricted in the first instance to parties involved in proper scientific assessment of the lava tubes that is directed towards meeting genuine management needs, not just opportunistic sojourns. It should be undertaken only by persons experienced in conducting research in caves, complying with the ASF minimal impact caving guidelines as a minimum requirement, and directed towards development of a special management plan for the lava tubes. Any underground recreation or tourism should be preceded by the installation of necessary protective infrastructure.

Effective protective management of caves is seldom easy, because there are important yet sensitive values and complex compering demands. At Heard Island, the few demands that exist should in theory be more simply dealt with than is the norm. The wilderness character and natural value of the Heard Island caves are enhanced by the fact that they occur in one of the wildest and most remote places on Earth. If the opportunity exists anywhere for a small set of caves to be left untrammelled by humankind, then this could be the ultimate place, if human curiosity, scientific ambition, economic pressures or politics will allow it to be achieved.

\section{ACKNOWLEDGEMENTS}

We thank Steve Reeve, Deputy Voyage leader for ANARE V5, 1996-97, for logistical assistance; Tony Yates for assistance in the field; Buck Rodger and Dennis Branch of Helicopters Australia for transferring us between the Aurora Australis and Azorella Peninsula under difficult conditions; Ron Greeley and Scot Harris for information from the NASA lava tube data base; Eric Colhoun and Mick Brown for comments on a draft; and Rick Perrin, Rod Ledingham and Maxine Wolf, Australian Antarctic Division. The fieldwork was made possible through a grant from the Antarctic Science Advisory Committee to Professor Eric Colhoun. This is Contribution No. 21 of the Geomorphology \& Quaternary Science Research Unit, Department of Geography and Environmental Science, University of Newcastle, Callaghan, NSW, Australia.

\section{REFERENCES}

Aley, T., 1975: Caves, cows and carrying capacity. Natl Cave Manage. Symp. Proc: 70-71. National Speleological Society.

ACIUCN (Australian Committee for IUCN), 1996: AUSTRALIAN NATURAL HERITAGE CHARTER. STANDARDS AND PRINCIPLES FOR THE CONSERVATION OF PLACES OF NATURAL HERITAGE SIGNIFICANCE. Australian Heritage Commission, Canberra. 18 pp.
ATKINSON, A. \& ATKINSON, V., 1995: UNDARA VOLCANO AND ITS LAVA TUBES. Anne \& Vernon Atkinson, Brisbane.

Audra, P., 1996: Inventaire preliminaire des cavernes de l'ile de la Reunion (Ocean Indien-France) Iere Partie. Lave (Revue de l'Association Volcanique Europeene) 61: 1627.

Australian Antarctic Division, 1995: HEARD ISLAND WILDERNESS RESERVE MANAGEMENT PLAN. Antarctic Division, Department of Environment, Sport \& Territories, Kingston, Tasmania: 72 pp.

Australian Speleological Federation Inc., 1990: CAVE SAFETY GUIDELINES. Pamphlet.

australian Speleological Federation Inc., 1995: MINIMAL IMPACT CAVING CODE. Pamphlet.

Baloga, S., Spudis, P.D. \& Guest, J.E., 1995: The dynamics of rapidly emplaced terrestrial lava flows and implications for planetary volcanism. J. Geophys. Res. 100: 24, 509.

Beaglehole, A.C. \& Learmonth, N.F., 1957: The Byaduk Caves. Vict. Nat. 73(12): 204-210.

Benedict, E.M., 1977: Hot air rises vs. cold air sinks. Speleograph 13: 73-77.

Bergstrom, D.M. \& SeppelT, R.D., 1988: The moss flora of Heard Island: revised checklist, annotations and phytogeographical considerations. Lindbergia 14: 184-190.

BRIGGS, T., 1992: A comparison of the troglobitic harvestmen from lava tubes and limestone caves. In Halliday, W.R. (Ed.): PROCEEDINGS OF THE THIRD INTERNATIONAL SYMPOSIUM ON VULCANOSPELEOLOGY, BEND, OREGON, 1982. International Speleological Foundation, Seattle: 131-132.

BROWN, P.L., 1957: TWELVE CAME BACK. Robert Hale, London.

Cashman, K., Pinkerton, H. \& Stephenson, J., 1998: Introduction to special section: long lava flows. J. Geophys. Res. Solid Earth Planets 103 (B11): 27 281-27 289.

Cessford, G. \& Dingwall, P.R., 1998 Research on shipborne tourism to the Ross Sea region and the New Zealand sub-Antarctic islands. Polar Rec. 34(189): 99-106.

ChapMan, P., 1993: CAVES AND CAVE LIFE. Harper Collins, London.

COOMBS, C. \& Rowland, S.H., 1994: Thermal erosion in a lava tube: Honoapo, Mauna Loa Volcano, Hawaii. Geol. Soc. Am. Ann. Meeting Abstr. 26(7): A118-119.

CRAWFORD, R.L., 1992: Biota of volcanic caves: an introduction. In Halliday, W.R. (Ed.): PROCEEDINGS OF THE THIRD INTERNATIONAL SYMPOSIUM ON VULCANOSPELEOOLOGY, BEND, OREGON, 1982. International Speleological Foundation, Seattle: $126-$ 129.

Cruikshank, D.P. \& Wood, C.A., 1972: Lunar rilles and Hawaiian volcanic features: posssible analogues. Moon 3: 412-447.

DarTnall, H.J.G., 1995: The rotifers of Heard Island: Preliminary survey, with notes on other feshwater groups. Pap. Proc. R. Soc. Tasm. 129: 7-15.

DAvEY, A.G., 1984: Evaluation criteria for the cave and karst heritage of Australia - Report of the ASF National Heritage Assessment Study. Helictite 15(2): 41-45.

Eberhard, S. \& Hamilton-Smith, E., 1996: Conservation of cave fauna in Australia. Australas. Cave Karst Manage. Assoc. Inc. J. 23: 4-14.

Favre, G., 1992: Some observations of Hawaiian pit craters and relations with lava tubes. In Halliday, W.R. (Ed.): PROCEEDINGS OF THE THIRD INTERNATIONAL SYMPOSIUM ON VULCANOSPELEOLOGY, BEND, $O R E G O N, 1982$. International Speleological Foundation, Seattle: 37-41.

GreELEY, R., 1991: Lava tubes in the solar system. In Rea, G.T. (Ed.): SIXTH INTERNATIONAL SYMPOSIUM ON 
VULCANOSPELEOLOGY, HILO, HAWAII, AUGUST 1991. National Speleological Society, Alabama: 286.

Greeley, R., Fagents, S.A., Harris, R.S., Kadfl, S.D., Williams, D.A. \& GUeST, J.E., 1998: Erosion by flowing lava: Field evidence. J. Geophys. Res. Solid Earth Planets 103(B11): $27,325-327,345$.

GressITT, J.L., 1970: Subantarctic entomology, particularly of South Georgia and Heard Island. Pac. Insects Monogr. 23: 121-151.

GRIMES, K. \& WATSON, T., 1995: Volcanic caves of western Victoria. In Baddeley, K. (Ed.): VULCON GUIDEBOOK. Victorian Speleological Association, Melbourne: Ch. 6.

HALLIDAY, W.R., 1977: Basic considerations in the management of ice caves and glacier caves. NATIONAL CAVE MANAGEMENT SYMPOSIUM PROCEEDINGS, BIG SKY, MONTANA, 3-7 OCTOBER 1977. Adobe Press, New Mexico, USA: 81-84.

HALliday, W.R., 1995: RESOURCES, VALUES AND MANAGEMENT OF PUNA CAVES. Report 95-01, Hawaii Speleological Survey of the National Speleological Society: $16 \mathrm{pp}$.

HALLIDAY, W.R., 1997: Unusual volcanic caves of Hawaii Island, Hawaii. PROCEEDINGS OF THE 12TH INTERNATIONAL CONGRESS OF SPELEOLOGY, 1997, SWITZERLAND 1: 449-452.

Harden, T.J. \& Hunt, P.J., 1985: Histoplasmosis and Australian cave environments. Helictite 23(1): 23-26.

HatHeWAY, A.W. \& HerRing, A.L., 1970: Bandera lava tubes of New Mexico, and Lunar implications. Commun. Lunar Planet. Lab., Univ. Arizona 8: 297-327.

HiLl, C.A. \& ForTi, P., 1986: CAVE MINERALS OF THE WORLD. National Speleological Society, Huntsville, Alabama.

Hon, K., Kauahikaua, J., Denlinger, R. \& Mackay, K., 1994: Emplacement and inflation of pahochoe sheet flows: Observations and measurements of active lava flows on Kilauea Volcano, Hawaii. Geol. Soc. Am. Bull. 106: 351370 .

Horne, P.A., 1984: Terrestrial invertebrates from McDonald Island and Heard Island, subantarctic. J. Aust. Entomol. Soc. $23(1): 38$

HowarTH, F.G., 1977: The cavernicolous fauna of Hawaian lava tubes, 1. Pac. Insects 15: 139-151.

HowarTH, F.G., 1981: Non-relictual terrestrial troglobites in the tropical Hawaiian caves. PROCEEDINGS OF THE 8TH INTERNATIONAL CAVE MANAGEMENT SYMPOSIUM, KENTUCKY. NSS.

HowarTH, F.G., 1992: Conservation of Hawaii's speleological resources. In Halliday, W.R. (Ed.): PROCEEDINGS OF THE THIRD INTERNATIONAL SYMPOSIUM ON VULCANOSPELEOLOGY, BEND, OREGON, 1982. International Speleological Foundation, Seattle: 124126.

HOWARTH, F.G., 1994: A comparison of the ecology and evolution of cave-adapted faunas in volcanic and karstic caves. In Oromi, P. (Ed.): SEVENTH INTERNATIONAL SYMPOSIUM ON VULCANOSPELEOLOGY. Federacion Espanola de Espeleologia \& Federacion Canaria de Espeleologia: 63-68.

HowarTh, F.G. \& STONE, F.D., 1990: Elevated carbon dioxide concentraions in Bayliss Cave, Australia: implications for the evolution of cave obligate species. Pac. Sci. 44: $207-$ 218.

Hunt, P.J., Harden, T.J., Hibins, M., Pritchard, R.C., Muir, D.B. \& GARDNER, F.J., 1984: Histoplasma capsulatum: Isolation from an Australian cave environment and from a patient, Med. J. Aust. 141: 280-283.

Ibister, J., Elliotot, M. \& Nogrady, S., 1976: Histplasmosis: An outbreak occurring among young men who visited one cave. Med.J. Aust. 2: 243-248.

Johnson, K.L., Wright, G. McK. \& Ashton, D.H., 1968:
Ecological studies of Tunnel Cave, Mt Eccles. Vict. Nat. 85: 350-356.

Jonsson, S.S., 1991: Preliminary speleological investigations in Surtsey. In Rea, G.T. (Ed.): SIXTH INTERNATIONAL SYMPOSIUM ON VULCANOSPELEOLOGY, HILO HAWAII, AUGUST 1991. National Speleological Society, Alabama: 89-94.

Joyce, E.B. \& WebB, J.A., 1992: Conservation of lava caves: examples from Australia. In Halliday, W.R. (Ed.): PROCEEDINGS OF THE THIRD INTERNATIONAL SYMPOSIUM ON VULCANOSPELEOLOGY, BEND, $O R E G O N$, 1982. International Speleological Foundation, Seattle: $121-123$

Kauahikaua, J., Cashman, K.V., Mattox, 'T.N., Heliker, C.C., Hon, K.A., Mangan, M.T. \& Thornder, C.R., 1998: Observations on basaltic lava streams in tubes from Kilauea Volcano, island of Hawai'i. J. Geophys. Res. Solid Earth Planets 103(B11): 27 345-27 358.

KEMPE, S. 1997: Lavafalls: a major factor for the enlargements of lava tubes on the Kilauea and Hualalai, Hawaii. PROCEEDINGS OF THE 12TH INTERNATIONAL CONGRESS OF SPELEOLOGY, 1997, SWITZERLAND 1: $445-448$

Kempe, S. \& Oberwinder, M., 1997: The upper Huehue flow (1801 eruption, Hualalai, Hawaii): An example of interacting lava flows yielding complex lava tube morphologies. PROCEEDINGS OF THE I2TH INTERNATIONAL CONGRESS OF SPELEOLOGY, 1997, SWITZERLAND 1: 449-452.

Kiernan, K., 1988: Karst management issues at the Jenolan tourist resort, NSW. In Gillieson, D.S. \& Smith, D.I. (Eds): RESOURCE MANAGEMENT IN LIMESTONE LANDSCAPES: INTERNATIONAL PERSPECTIVES. Spec. Publ. 2. Department of Geography and Oceanography, University College, Australian Defence Force Academy, Canberra: 111-132.

Kiernan, K., 1997: Scientific research in karst: environmental impacts. Cave Manage. Australas. 11: 222-233.

Kiernan, K., McConnell, A. \& Yates, T., 1998: Tube-fed pahoehoe lava flow features of Azorella Peninsula, subantarctic Heard Island, southern Indian Ocean. Polar Rec. 34(190): 225-236.

LAzER, E \& MCGOWAN, A., 1990: HEARD ISLAND ARCHAEOLOGICAL SURVEY 1986-87. Department of Architectural \& Design Science, University of Sydney: $130 \mathrm{pp}$.

Mandis Roberts Consultants, 1994: DETERMINING AN ENVIRONMENTAL AND SOCIAL CARRYING CAPACITY FOR JENOLAN CAVES RESERVE. Jenolan Caves Reserve Trust.

Mattox, T.N., Heliker, C., Kauahikaua, J. \& Hon, K., 1993: Development of the 1990 Kalapana flow field, Kilauea Volcano, Hawaii. Bull. Volcanol. 55: 407-413.

Middleton, G.J. \& HalliddaY, W.R., 1997: Caves of the Republic of Mauritius, Indian Ocean. PROCEEDINGS OF THE 12TH. INTERNATIONAL CONGRESS OF SPELEOLOGY, 1997, SWITZERLAND 1: 437-440.

Muchmore, W.B., 1982: A new cavernicolous Sathrochthonius from Australia (Pseudoscorpionida: Chthoniidae). Pac. Insects 24: 156-158.

Nieland, J., Nieland, L. \& Benedict, E., 1977: Special management considerations of lava caves. NATIONAL CAVE MANAGEMENT SYMPOSIUM PROCEEDINGS, BIG SKY, MONTANA, 3-7 OCTOBER 1977. Adobe Press, New Mexico, USA: 85-91

Northup, D.E., Layole, K, \& Maliory, L., 1997: Microbes in caves. Nat. Speleol. Soc. News 55(4): 111.

Olu.er, C.D. \& Brown, M.C., 1965: Lava caves of Victoria. Bull. Volcanol. 28: 215-229.

Olsen, S.L. \& Wermore, A., 1976: Preliminary diagnoses of two extraordinary new genera of birds from Pleistocene 
deposits in the Hawaiian Islands. Proc. Biol. Soc. Washingon 89: 247-258.

Peterson, D.W. \& SWAnson, D.A., 1974: Observed formation of lava tubes during 1970-1971 at Kilauea Volcano, Hawaii. Stud. Speleol. 2(6): 209-224.

Pilkington, E.S. \& SEgnit, E.R., 1979: Taranakite from the Skipton Caves, Victoria, Australia. Aust. Mineral. 75 : 159-160.

RiFEnBURGH, B., 1998: Impacts on the Anactic environment: tourism vs. government programmes. Polar Rec. 34(190): 193-196.

ScorT, J.J., 1990: Changes in vegetation on Heard Island $1947-$ 1987. In Kerry, K.R. \& Hempel, G. (Eds): ANTARCTIC ECOSYSTEMS. ECOLOGICAL CHANGE AND CONSERVATION. Springer Verlag, Berlin.

Sefshol.tz, D., 1977: The management plan for the lava caves area on Mt St Helens, NATIONAL CAVE MANAGEMENT SYMPOSIUM PROCEEDINGS, BIG SKY, MONTANA, 3-7 OCTOBER 1977. Adobe Press, New Mexico, USA: 32-33.

SkINner, C.E., 1992: Open vertical volcanic conduits: a preliminary investigation of an unusual volcanic cave form with examples from Newberry Volcano and the central high Cascades of Oregon. In Halliday, W.R. (Ed.): PROCEEDINGS OF THE THIRD INTERNATIONAL SYMPOSIUM ON VULCANOSPELEOLOGY, BEND, OREGON, 1982. International Speleological Foundation, Seattle: 7-17.

SlezIN, N. \& Tsyurupa, A.I., 1994: Lava caves in Kamchatka. In Oromi, P. (Ed.): SEVENTH INTERNATIONAL SYMPOSIUM ON VULCANOSPELEOLOGY. Federacion Espanola de Espeleologia \& Federacion Canaria de Espeleologia: 113-120.

Solomon, S.B., Langroo, R., Peggie, J.R., Lyons, R.G. \& JAMES, J.M., 1996: OCCUPATIONAL EXPOSURE TO RADON IN AUSTRALIAN TOURIST CAVES. AN AUSTRALIA-WIDE STUDY OF RADON LEVELS. Final report of Worksafe Australia Research Grant (93/0436). Australian Radiation Laboratory Report ARL/TR119: 16 pp.
Spate, A. \& Hamilton-Smith, E., 1991: Cavers' impacts some theoretical and applied considerations. In Bell, P. (Ed.): PROC. 9TH AUSTRAL. CAVE \& KARST MANAGEMENT ASSOC. CONF: 20-30.

Stefanson, A.B., 1991: Prihnukargigur. In Rea, G.T. (Ed.) SIXTH INTERNATIONAL SYMPOSIUM ON VULCANOSPELEOLOGY. HILO, HAWAII, AUGUST 1991. National Speleological Society, Alabama: 197200.

WAKEFIELD, N.A., 1964: Mammal sub-fossils from basalt caves in south western Victoria. Vict. Nat. 80: 274-278.

WALKER, G.P.L., 1991: Structure, and origin by injection of lava under surface crust, of tumuli, "lava rises", "lava rise pits", and "lava inflation clefts" in Hawaii. Bull. Volcanol. 53: 546-558.

Watson, J., Hamilton-Smith, E., Glllieson, D. \& Kiernan, K. (EDS), 1997: GUIDELINES FOR CAVE AND KARST PROTECTION. IUCN, Gland, Switzerland and Cambridge, UK: $63 \mathrm{pp}$.

WEBB, J.A., 1986: Cave minerals in Victoria. Nargun 19(1): 10 15.

WebB, J.A., Joyce, E.B. \& SteVens, N.C., 1992: Lava caves of Australia. In Halliday, W.R. (Ed.): PROCEED NNGS OF THE THIRD INTERNATIONAL SYMPOSIUM ON VULCANOSPELEOLOGY, BEND, OREGON, 1982. International Speleological Foundation, Seattle: 74-85.

Williams, P., 1975: Report on the conservation of Waitomo Caves. NZ Speleol. Bull. 5(93): 373-395.

Wood, C., 1992: A scientific rationale for vulcanospeleology. In Halliday, W.R. (Ed.): PROCEEDINGS OF THE THIRD INTERNATIONAL SYMPOSIUM ON VULCANOSPELEOOLOGY, BEND, OREGON, 1982. International Speleological Foundation, Seattle: 105-107.

Wrigley, T.L. \& Brown, M.C., 1976: The physics of caves. In Ford, T.D. \& Cullingford, C.H.D. (Eds): THE SCIENCE OF SPELEOLOGY. Academic Press, London: 329-358.

(accepted 6 September 1999) 